\title{
Assessment of Spatial-temporal Distribution of Observed Salinity Based on Location and Water Depth in Can Gio Area, Southern Vietnam
}

THU, Vu Thi Hoai

Laboratory of Water Environment Engineering, Course of Bioproduction Environmental Sciences, Department of Agro-environmental Sciences, Graduate School of Bioresource and Bioenvironmental Sciences, Kyushu University | Thuyloi University

TABATA, Toshinori

Laboratory of Water Environment Engineering, Division of Bioproduction Environmental Sciences, Department of Agro-environmental Sciences, Faculty of Agriculture, Kyushu University

HIRAMATSU, Kazuaki

Laboratory of Water Environment Engineering, Division of Bioproduction Environmental Sciences, Department of Agro-environmental Sciences, Faculty of Agriculture, Kyushu University

NGOC, Trieu Anh

Thuyloi University | Laboratory of Water Environment Engineering, Division of Bioproduction Environmental Sciences, Department of Agro-environmental Sciences, Faculty of Agriculture, Kyushu University

他

https://doi.org/10.5109/1955659

出版情報：九州大学大学院農学研究院紀要. 63 (2)，pp.379-385，2018-09-01. Faculty of Agriculture, Kyushu University

バージョン :

権利関係 : 


\title{
Assessment of Spatial-temporal Distribution of Observed Salinity Based on Location and Water Depth in Can Gio Area, Southern Vietnam
}

\author{
Vu Thi Hoai THU1,2, Toshinori TABATA*, Kazuaki HIRAMATSU, \\ Trieu Anh NGOC ${ }^{2}$ and Masayoshi HARADA
}

\author{
Laboratory of Water Environment Engineering, Division of Bioproduction Environmental Sciences, \\ Department of Agro-environmental Sciences, Faculty of Agriculture, \\ Kyushu University, Fukuoka 812-8581, Japan \\ (Received April 16, 2018 and accepted May 8, 2018)
}

\begin{abstract}
The Can Gio mangrove forest in southern Vietnam hosts abundant ecological resources and plays an important role in protecting Ho Chi Minh City from storms in the East Sea. This area is currently facing environmental problems, including changes in water salinity that affect mangrove health, because of the complexity of the local river system. Freshwater from the Sai Gon - Dong Nai River system mixes with seawater from the East Sea, altering salinity at different locations along with the effects of the tidal regime. In this study, we surveyed the spatial-temporal distribution of salinity in the Can Gio area with referenec to location and river depth using commercial data loggers to record salinity time series at two locations and salinity depth profiles at 24 locations along the two main rivers in the area. Our results showed that salinity steadily declined upstream from the sea and was strongly affected by the tide regime. Salinity also changed based on the water depth, the hydrodynamic effects of current and river channel width.
\end{abstract}

Key words: salinity, field observation, spatial-temporal distribution, vertical profile, tidal regime

\section{INTRODUCTION}

The Can Gio mangrove forest, located $\sim 50 \mathrm{~km}$ southeast of Ho Chi Minh City (HCMC), Vietnam, is considered an international biosphere reserved zone (UNESCO, 2000). Located in the deltaic confluence of the SaigonDong Nai and Vam Co Rivers, it protects that city against storms from the East Sea. Can Gio is an important environmental resource for the surrounding area, hosting about 105 plant species and 150 species of aquatic fauna. The area also supports a variety of wildlife such as wild pigs, monkeys, otters, saltwater crocodiles, many species of snakes, and abundant birds including rare species. Moreover, Can Gio plays a crucial role in the developing economy around HCMC, supporting jobs in aqua agriculture, fisheries, shrimping, and ecotourism. The area also hosts a main shipping channel via the Long Tau and Soai Rap Rivers, allowing ships of less than 20,000 tons carrying capacity to enter HCMC at the ports of Cat Lai and Phu Huu.

Can Gio covers approximately 70,400 ha, of which 32,000 ha are mangrove forest. It is bounded by the Nha Be District of HCMC in the north, the East Sea in the south, Dong Nai and Ba Ria - Vung Tau Provinces in the east, and Long An and Tien Giang Provinces in the west (Fig. 1). The area has a typical monsoonal climate with two distinct seasons (Tuan et al., 2002): a dry season from November to May and a wet season from June to

\footnotetext{
${ }^{1}$ Laboratory of Water Environment Engineering, Course of Bioproduction Environmental Sciences, Department of Agroenvironmental Sciences, Graduate School of Bioresource and Bioenvironmental Sciences, Kyushu University

2 Thuyloi University, No. 2 Truong Sa, Binh Thanh, Ho Chi Minh City, Vietnam

* Corresponding author (E-mail: ttabata@bpes.kyushu-u.ac.jp)
}

October. It has a bi-diurnal tidal regime with two ebb and flood tides per day (van Loon et al., 2007); tidal amplitudes range from $\sim 2-4 \mathrm{~m}$ from mean tide to spring tide. Tides are highest from September to January and lower in other months, with a maximum in October or November and a minimum in April or May (Binh et al., 2008).

Can Gio has a very complex network of rivers ranging in length from 10-70 km with depths up to $30 \mathrm{~m}$; rivers account for $31.76 \%$ of the total area (Nguyen, 2011). Freshwater from the Sai Gon-Dong Nai River is carried toward the sea via its two main branches (the Long Tau and Soai Rap Rivers) and also via subordinate branches such as the Thi Vai River. Most of the water in Can Gio is generally brackish due to the mixing of freshwater and seawater, which is of great importance to the area's two main estuaries, Dong Tranh and Ganh Rai.

The Can Gio area faces a number of environmental issues, particularly changes in water quality that relate to salinity change and can lead to detrimental effects on the mangrove forest as salinity is a key environmental factor for plant growth and productivity (Allakhverdiev et al., 2000). Salinity fluctuations in this area are directly correlated with the combined effects of the tidal regime and the Sai Gon and Dong Nai Rivers' flow; the salinity is highest during high tide and lowest during low tide, while higher river flow reduces salinity by pushing seawater further seaward. Other factors influencing salinity levels include regulated flows from the upstream Tri An and Dau Tieng Reservoirs and river depth. Due to morphological differences between the Soai Rap and Long Tau Rivers, these channels are affected differently by the tidal regime of the East Sea: the former has a lower salinity than the latter because of its shallow cross-section. In other words, the sea's tidal impact on the shallower Soai Rap River is less than on the deeper Long Tau 


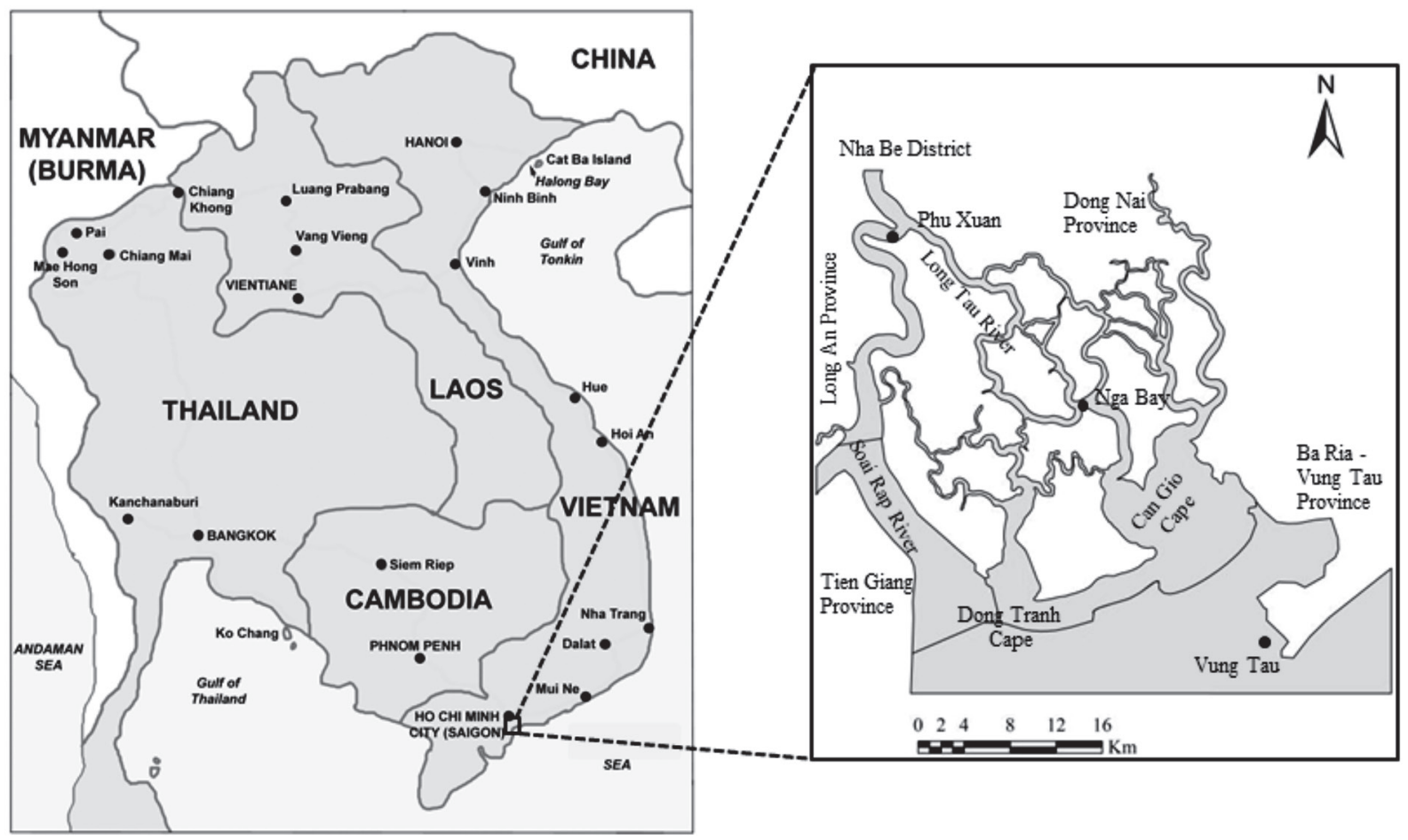

Fig. 1. Location of the Can Gio mangrove forest along the Soai Rap and Long Tau Rivers in southern Vietnam. A HOBO U24 Conductivity Logger was set up at the locations marked Phu Xuan and Nga Bay to record salinity time series in ten-minute-intervals.

River. The salinity in Can Gio also differs depending on the season. Salinity increases in the dry season as seawater penetrates further inland, peaking in March and April at 19-20 psu in the north, and 26-30 psu near the sea. Salinity declines in the rainy season, bottoming out from August to November at only 4-8 psu in the mangrove forest. The average monthly salinity for the area over the entire year is approximately $18 \mathrm{psu}$ (Hong, 2004). Salinity is an essential key to environmental research and management in fields such as climate science and oceanography, water quality monitoring, and coastal management. In this study, we collected salinity data within the Can Gio region to assess and understand the spatial-temporal distribution of salinity with regards to river depth and the impact of tidal regimes. Our results provide a better context for understanding salinity fluctuations in the area and their importance for management of the Can Gio ecosystem.

\section{MATERIALS AND METHODS}

There are a number of available instruments that provide salinity data by measuring electric conductivity and temperature, then deriving salinity from these measurements. We used a HOBO U24 Conductivity data logger (U24-002-C) (Fig. 2, Table 1) to collect salinity time series at two locations within Can Gio (Fig. 1). Phu Xuan Station, in the upstream portion, represents an area that directly affects HCMC, while Nga Bay Station (Fig. 4 ) is located in the middle of the mangrove forest. Both are important locations for assessing changes in salinity with reference to the tidal regime and upstream discharge in this region.

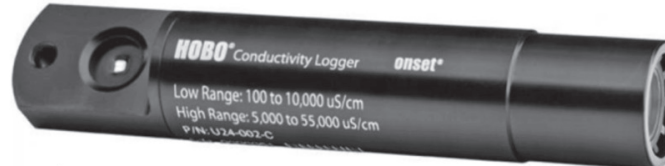

Size: $16.50 \times 3.18 \mathrm{~cm}$ (Height $\mathrm{x}$ Diameter)

Fig. 2. HOBO U24 Conductivity data logger (U24-002-C).

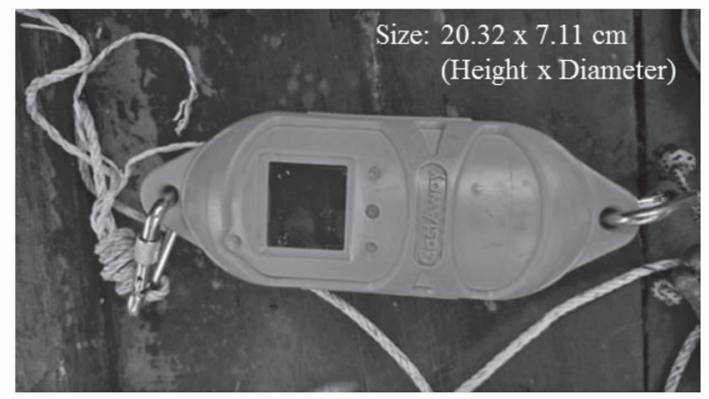

Fig. 3. CastAway CTD data logger.

From December 7-8, 2017, the HOBO U24 Conductivity Logger was set up at Phu Xuan Station and Nga Bay Station on December 8-10, 2017 approximately $2 \mathrm{~m}$ beneath the water's surface. The logger was kept in a polyvinyl chloride (PVC) pipe housing and secured to a line that was anchored and connected to the station so as to maintain correct orientation and location. The instrument recorded electric conductivity and temperature at ten-minute-intervals.

In addition, we used a CastAway CTD data logger 
Table 1. HOBO U24 conductivity data logger specifications

\begin{tabular}{ll}
\hline Operating Range & $2^{\circ}$ to $36^{\circ} \mathrm{C}$ \\
Memory & $64 \mathrm{~KB}$ \\
Sample Rate & 1 second to $18 \mathrm{hrs}$ \\
Battery & 3.6 Volt lithium battery \\
Battery Life & 3 years (at 1 minute logging) \\
Maximum Depth & $70 \mathrm{~m}$ \\
Weight & $193 \mathrm{~g}$ \\
Size & $3.18 \mathrm{~cm}$ diameter $\times 16.5 \mathrm{~cm}$, with \\
& $0.63 \mathrm{~cm}$ mounting hole \\
\hline
\end{tabular}

Table 2. CastAway CTD data logger specifications

\begin{tabular}{ll}
\hline Operating Range & $-5^{\circ}$ to $45^{\circ} \mathrm{C}$ \\
Memory & $15 \mathrm{MB}$ \\
Sample Rate & $5 \mathrm{~Hz}$ \\
Battery & $2 \mathrm{AA}$ alkaline batteries \\
Battery Life & 40 hours continuous use \\
Maximum Depth & $100 \mathrm{~m}$ \\
Weight & $0.45 \mathrm{~kg}$ \\
Size & $7.11 \mathrm{~cm}$ diameter $\times 20.32 \mathrm{~cm}$ \\
\hline
\end{tabular}

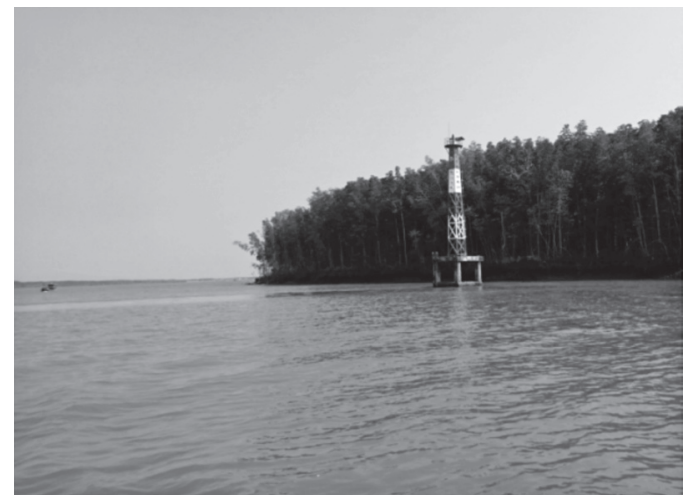

Fig. 4. Nga Bay Station.

(Fig. 3, Table 2) to collect salinity profiles at 24 points along the Soai Rap and Long Tau Rivers and a small branch connecting Dong Tranh Cape and Can Gio Cape on December 10, 2017 (Fig. 5). Points 1, 2, and 3 were located in the upstream portion of Can Gio to study the changes of salinity near HCMC. Points 3 to 14 were located in the Long Tau River. Points a, b, and c were located in a small branch connecting Can Gio Cape to Dong Tranh Cape. Points 15 to 21 were located in the Soai Rap River. This instrument uses a built-in GPS receiver to record its location in both time and space, noting latitude and longitude before and after each profile. It is a small, rugged, and technically advanced instrument designed for profiling to depths of up to $100 \mathrm{~m}$ that provides salinity data within the accuracy levels requires for coastal monitoring applications (ACT, 2007). In the field, the CastAway LCD screen plots electric conductivity, temperature, and salinity versus depth immediately. The data logger was connected to a reel and typically

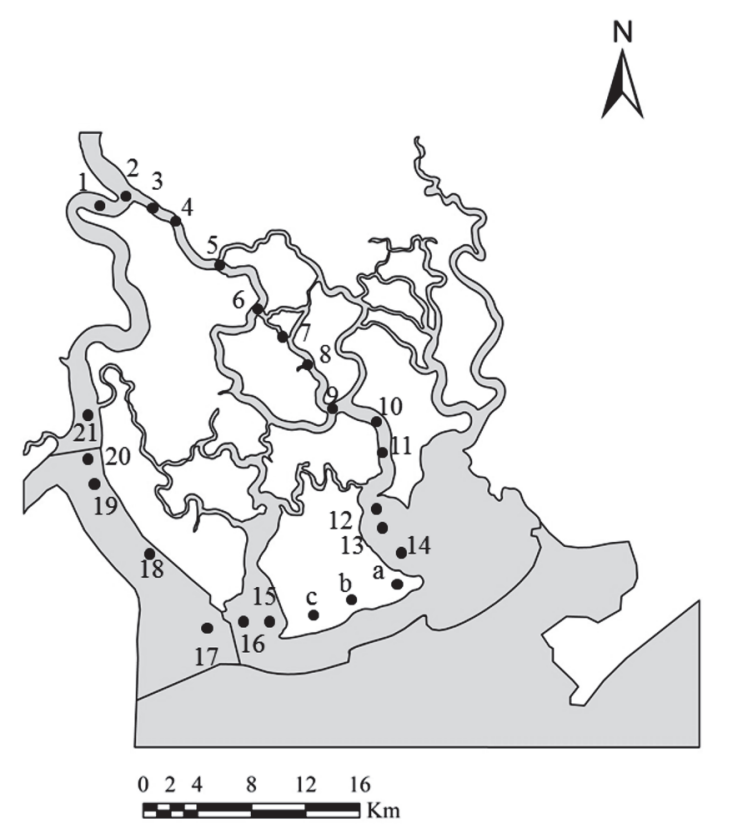

Fig. 5. Locations of salinity profiles taken by the CastAway CTD data logger.

lowered from a boat by hand; salinity, temperature, and pressure data were collected from surface to bottom.

\section{RESULTS AND DISCUSSIONS}

\section{Effects of water level on salinity}

The surface salinity ranged from $1.6-6 \mathrm{psu}$ at Phu Xuan Station (Fig. 6) and from 15-20.5 psu at Nga Bay Station (Fig. 7). These fluctuations were clearly driven by tidal stage but also depended on station location: the amplitude of change at Phu Xuan Station (about $40 \mathrm{~km}$ from the sea) was about $4.4 \mathrm{psu}$ while that at Nga Bay Station (20 km from the sea) was about $5.5 \mathrm{psu}$. In addition, the maximum and minimum salinities were affected by the hydrodynamic regime. The maximum water level at Vung Tau Station occurred at 17:00 on December 7, 2017, but the peak salinity at Phu Xuan Station occurred at 21:00, a four hour lag from the peak tidal level at the sea. This delay was prominent at Nga Bay Station, where peak salinity occurred shortly at 20:30, a 2.5 hour lag after the peak tidal level at 18:00 on December 8, 2017.

\section{Vertical distribution of salinity}

Salinity was strongly influenced by water depth; in almost all profiles salinity was higher toward the riverbed and lower near the surface (Fig. 8, Table 3). At the river junction near Phu Xuan Station (points 1, 2, and 3), the salinity ranged from 1-6 psu despite very different depth profiles, but fluctuation of salinity was quite different. The point 1, 2, 3 of Fig. 8 pointed out, observed salinity around Phu Xuan Station had the significant variation at the same recording time. Point 1 of Fig. 8 showed the salinity slightly changed from 3.0 to $4.0 \mathrm{psu}$ from top to bottom, point 2 fluctuated in the range of $3.1-4.1 \mathrm{psu}$. Meanwhile, the profile of point 3 had sharply changed of 3.6-7.1 psu. This pointed that, the Soai Rap River con- 

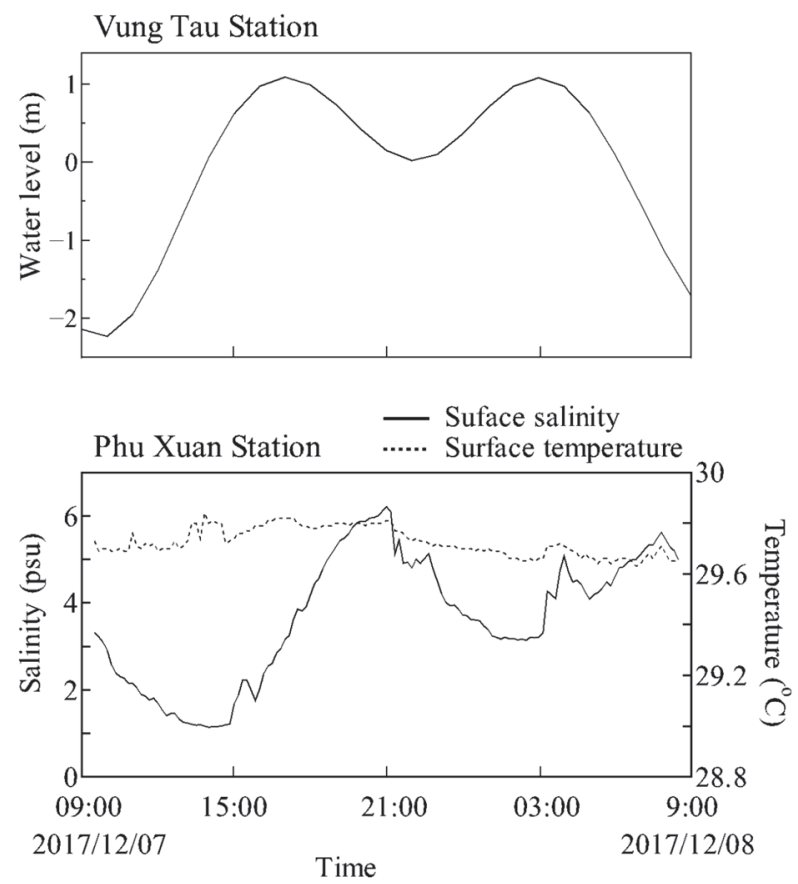

Fig. 6. Calculated tidal level at Vung Tau Station and time series of surface salinity and temperature at Phu Xuan Station from 09:30 (local time) December $7^{\text {th }}$ to 08:30 December $8^{\text {th }}, 2017$.
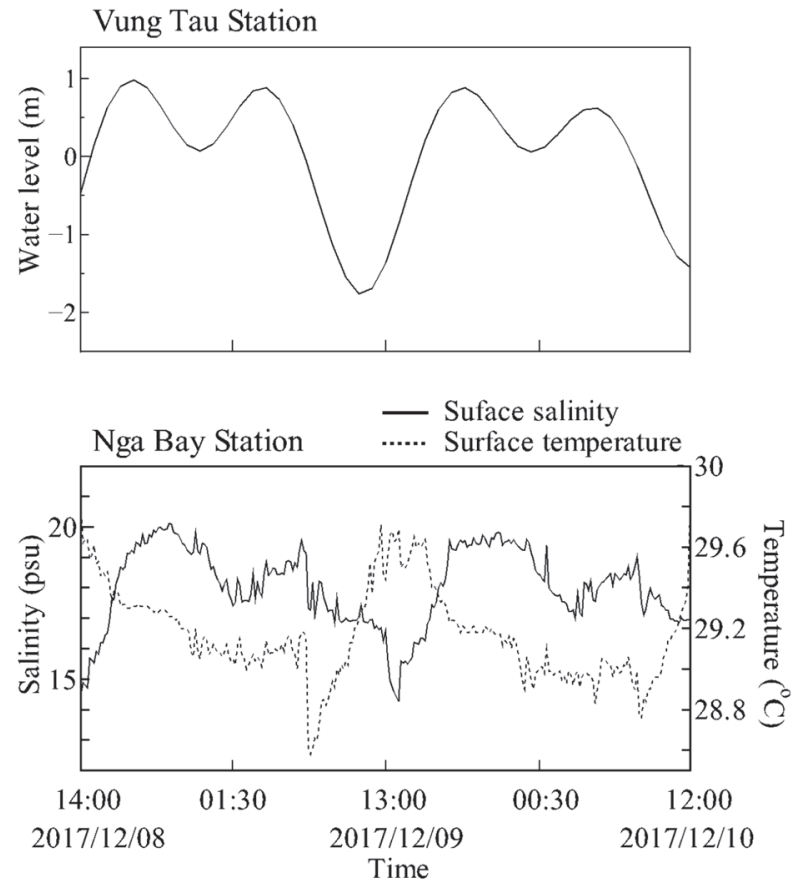

Fig. 7. Calculated tidal level at Vung Tau Station and time series of surface salinity and temperature at Nga Bay Station from 14:00 (local time) December $8^{\text {th }}$ to 12:00 December $10^{\text {th }}, 2017$.
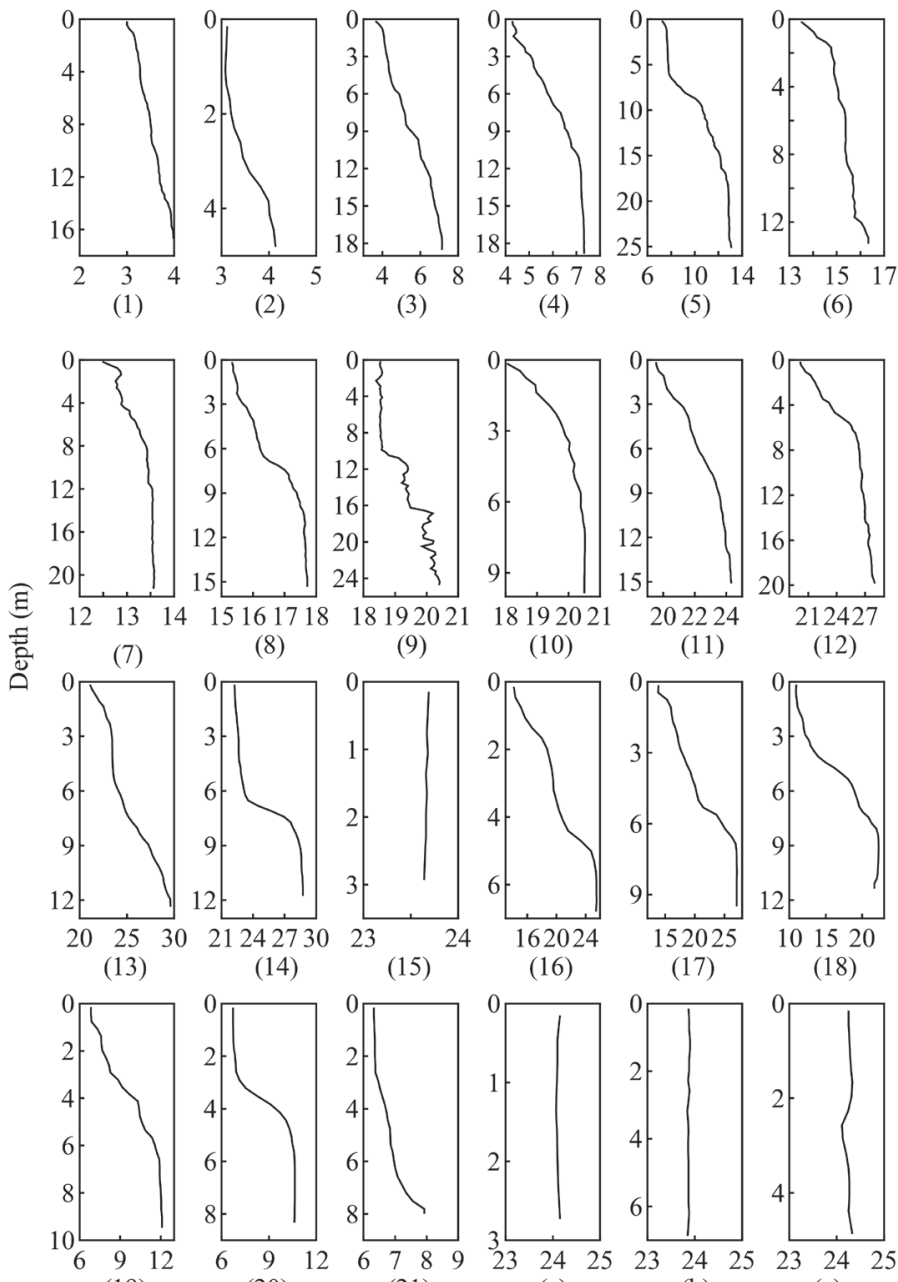

(8)
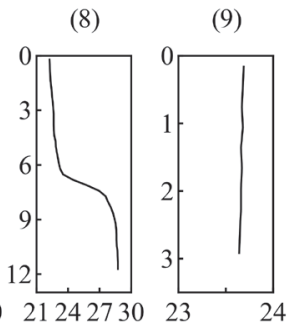

(10)
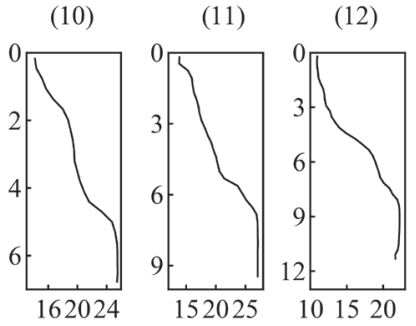

(14)

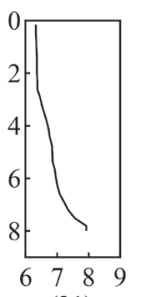

(21)

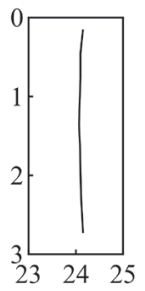

(a)

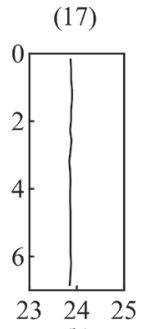

(b)

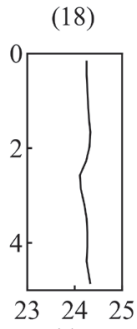

(c)

Fig. 8. Salinity profiles at the 24 observation points (Fig. 5) recorded on December 10, 2017. 
Table 3. Observed salinity values at the water's surface and bottom for 24 observation points (see Fig. 5)

\begin{tabular}{|c|c|c|c|c|c|c|}
\hline Point & $\begin{array}{c}\text { Time } \\
\text { (December } \\
10,2017 \text { ) }\end{array}$ & $\begin{array}{l}\text { Distance to Vung } \\
\text { Tau Station }(\mathrm{km})\end{array}$ & Observatio & th (m) & $\begin{array}{c}\text { Salinity at } \\
\text { observation depths } \\
\text { (psu) }\end{array}$ & $\begin{array}{l}\text { Depth-averaged } \\
\text { salinity (psu) }\end{array}$ \\
\hline \multirow{2}{*}{1} & \multirow{2}{*}{ 09:02 } & \multirow{2}{*}{48.00} & Surface & 0.15 & 3.00 & \multirow{2}{*}{3.52} \\
\hline & & & Bottom & 16.67 & 3.98 & \\
\hline \multirow{2}{*}{2} & \multirow{2}{*}{ 09:16 } & \multirow{2}{*}{46.63} & Surface & 0.15 & 3.08 & \multirow{2}{*}{3.48} \\
\hline & & & Bottom & 4.80 & 4.14 & \\
\hline \multirow{2}{*}{3} & \multirow{2}{*}{ 09:23 } & \multirow{2}{*}{45.26} & Surface & 0.15 & 3.63 & \multirow{2}{*}{5.59} \\
\hline & & & Bottom & 18.13 & 7.14 & \\
\hline \multirow{2}{*}{4} & \multirow{2}{*}{ 09:32 } & \multirow{2}{*}{43.43} & Surface & 0.15 & 4.28 & \multirow{2}{*}{6.33} \\
\hline & & & Bottom & 18.43 & 7.33 & \\
\hline \multirow{2}{*}{5} & \multirow{2}{*}{$10: 00$} & \multirow{2}{*}{38.87} & Surface & 0.15 & 7.21 & \multirow{2}{*}{10.72} \\
\hline & & & Bottom & 24.67 & 13.08 & \\
\hline \multirow{2}{*}{6} & 10.26 & 3474 & Surface & 0.15 & 13.49 & 1528 \\
\hline & 10.20 & 04.14 & Bottom & 13.09 & 16.34 & 10.20 \\
\hline 7 & $11 \cdot 18$ & 3212 & Surface & 0.15 & 12.48 & 1331 \\
\hline 1 & 11.10 & 02.18 & Bottom & 21.26 & 13.58 & 13.31 \\
\hline 8 & $11 \cdot 33$ & 2971 & Surface & 0.15 & 15.33 & 1675 \\
\hline 0 & 11.00 & 29.11 & Bottom & 15.13 & 17.72 & 10.10 \\
\hline 9 & 11.53 & 2606 & Surface & 0.15 & 18.54 & 1927 \\
\hline 9 & $11: 53$ & 20.00 & Bottom & 24.46 & 20.39 & 19.28 \\
\hline 10 & $12 \cdot 11$ & 2286 & Surface & 0.15 & 18.05 & 1997 \\
\hline & & & Bottom & 9.86 & 20.52 & 15.31 \\
\hline 11 & 12.22 & 2103 & Surface & 0.15 & 19.54 & 2256 \\
\hline & & & Bottom & 15.11 & 24.32 & \\
\hline 12 & $12: 43$ & 1783 & Surface & 0.15 & 20.14 & 2563 \\
\hline & & & Bottom & 19.84 & 28.04 & \\
\hline 13 & 12.54 & 1646 & Surface & 0.15 & 21.08 & 25.14 \\
\hline 10 & 12.04 & 10.40 & Bottom & 12.36 & 29.61 & 20.14 \\
\hline 14 & $13 \cdot 00$ & 14.17 & Surface & 0.15 & 22.23 & 24.96 \\
\hline & & & Bottom & 11.77 & 28.73 & \\
\hline a & $13 \cdot 16$ & 1281 & Surface & 0.15 & 24.07 & 2411 \\
\hline$a$ & 10.10 & 12.01 & Bottom & 2.73 & 24.14 & 84.11 \\
\hline b & 14.06 & 15.54 & Surface & 0.15 & 23.84 & 2387 \\
\hline & & & Bottom & 6.87 & 23.9 & \\
\hline$c$ & 14.51 & 1791 & Surface & 0.15 & 24.11 & 2425 \\
\hline 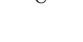 & & & Bottom & 4.86 & 24.33 & \\
\hline 15 & $15 \cdot 17$ & 20.57 & Surface & 0.15 & 23.69 & 23.66 \\
\hline & & & Bottom & 2.90 & 23.64 & \\
\hline 16 & $15: 37$ & 22.41 & Surface & 0.15 & 14.16 & 20.60 \\
\hline & & & Bottom & 6.73 & 25.43 & \\
\hline 17 & $15 \cdot 47$ & 2469 & Surface & 0.15 & 13.86 & 2151 \\
\hline & & & Bottom & 9.40 & 27.09 & \\
\hline 18 & $16 \cdot 20$ & 28.34 & Surface & 0.15 & 10.96 & 1727 \\
\hline 10 & 10.20 & 20.04 & Bottom & 11.21 & 21.68 & 17.21 \\
\hline 19 & 16.50 & 3611 & Surface & 0.15 & 6.84 & 988 \\
\hline & & & Bottom & 9.30 & 12.10 & \\
\hline 20 & 16.56 & 3749 & Surface & 0.15 & 6.72 & 894 \\
\hline & & & Bottom & 8.17 & 10.62 & \\
\hline 21 & 19.09 & 3886 & Surface & 0.15 & 6.33 & 679 \\
\hline 21 & 19.09 & 00.00 & Bottom & 7.83 & 7.93 & 0.19 \\
\hline
\end{tabular}


taining most of the downstream flow compared to the smaller Long Tau River.

Along the upper Long Tau River (above Nga Bay Station), from points 3 to 9 , the salinity change from top to bottom ranged mostly between $2-4 \mathrm{psu}$, though each profile followed a similar increasing trend with water depth. One exception occurred at point 5, where the salinity increased from $7.2 \mathrm{psu}$ to $13.1 \mathrm{psu}$ because this location is the intersection point of the upstream branch of Long Tau River which received a massive amount of water from Sai Gon - Dong Nai River system and two downstream branches of Long Tau River. Overall, the maximum salinity increased in a seaward direction, except at point 6 and point 7 , the salinity of point 7 was lower than point 6 . The reason for this difference was that point 7 which was located at a small branch of the Long Tau River and so received less saltwater than point 6. The salinity at points 7,8 , and 9 changed only a little from top to bottom because these points were located in an area of high water velocity which mixed the freshwater and saltwater more thoroughly, thus there was not so different between salinity in top and bottom of water.

Along the lower Long Tau River (downstream from Nga Bay station), the salinity range for points 10 to 14 reached $8 \mathrm{psu}$, and the vertical profiles changed downstream. The river's cross-section underwent significant change over this stretch and the confluence of many tributaries caused hydrodynamic changes in addition to the salinity variations. This was particularly true for points 12, 13, and 14 located along Can Gio Cape at the intersection of the river and the sea, where the river was especially wide and the water velocity was low. Thus the mixing of freshwater from rivers and saltwater from the sea was not strong, leading to a more segregated salinity profile as the denser (and more saline) seawater remained below the less dense freshwater.

Along the Soai Rap River, from points 16 to 21, the salinity at the bottom was always higher in shallower water, but the vertical profile did not follow a similar trend as in the Long Tau River. The salinity changed dramatically in the top layer of water and but only increased insignificantly in the bottom layer. At points 16, 17, and 18 at the mouth of the Soai Rap River, where the channel was wider than the Long Tau River, the salinity range from top to bottom was more than $10 \mathrm{psu}$, higher than observed in the latter. Point 19 and 20, located at the intersection of the Soai Rap and Vam Co Rivers, had higher water velocity, so the range from top to bottom of water was lower than at points 16,17 , and 18 .

However, the general trend of salinity rising with water depth was not applicable at points 15, a, b, and c, along the branch connecting Can Gio Cape to Dong Tranh Cape. At these locations, the salinity changed very little or in either direction with depth; point 15 actually showed decreased salinity from top to bottom over $3 \mathrm{~m}$ depth. This suggests that, when water current is almost static and the hydrodynamic regime changes slowly, the salinity is almost unaffected by the water depth.

The amplitude of salinity between the top and bottom of the river depended on the flow regime and magni- tude of velocity as well as water depth. The salinity in the sea exceeded $30 \mathrm{psu}$, declining to $23 \mathrm{psu}$ at the mouth of the Soai Rap River and 25 psu at the mouth of the Long Tau River. The salinity in the latter was higher than in the former because latter was deeper and narrower. The salinity in the Soai Rap River declined to about 9 psu at the intersection with the Vam Co River and further decreased to 3 psu upstream at Phu Xuan Station. The salinity in the Long Tau River declined to about 20 psu at Nga Bay Station and decreased to 3 psu at Phu Xuan Station.

\section{CONCLUSIONS}

We collected salinity, temperature, depth, and other readings in several river channels within the Can Gio mangrove forest of southern Vietnam during the wet season, from December 7-10, 2017. Our results showed that the salinity declined from upstream to downstream (toward the sea) at about $0.5 \mathrm{psu} / \mathrm{km}$. However, the range of salinity in the vertical profile differed by location and water depth. The Long Tau River was deeper and narrower than the Soai Rap River and thus had higher salinity. The salinity profiles were also affected by proximity to the sea; at Dong Tranh Cape the surface salinity ranged from 10-14 psu in comparison with the bottom salinity of 22-27 psu, with a sharp gradient between them showing less mixing than in upstream areas; a similar pattern was observed at Can Gio Cape, despite a lower salinity range. Finally, the salinity profiles were strongly influenced by the tidal regime of the area, with tidal effects particularly significant near the river mouths and weakening upstream toward Phu Xuan Station.

\section{AUTHOR CONTRIBUTIONS}

V. T. H. THU and T. TABATA designed the study, conducted the field observations and wrote the manuscript. T. A. NGOC contributed the field observations. K. HIRAMATSU and M. HARADA assisted in the preparation of the manuscript. All authors approved the final version of the manuscript, and agree to be accountable for all aspects of the work in ensuring that questions related to the accuracy or integrity of any part of the work are appropriately investigated and resolved.

\section{ACKNOWLEDGEMENTS}

The authors appreciate the funding support of JSPS KAKENHI under Grant Number 17K15347. The authors wish to thank Dr. Shinji Fukuda from Tokyo University of Agriculture and Technology for providing the CastAway CTD data logger.

\section{REFERENCES}

Allakhverdiev, S. I., A. Sakamoto, Y. Nishiyama, M. Inaba and N. Murata 2000 Ionic and osmotic effects of NaCl-induced inactivation of photosystems I and II in Synechococcus sp. Plant Physiology, 123(3): 1047-1056

Alliance for Coastal Technologies (ACT) 2007 State of Technolo- 
gy for In Situ Measures of Salinity Using Conductive Temperature Sensors, Savannah, Georgia, December 3-5, 2007: workshop proceedings. Solomons, MD, Alliance for Coastal Technologies, (ACT 07-05; UMCESCBL 08-056)

Binh, T. T. H., P. V. Hoa, L. K. Thoa and N. V. Luong 2008 Using multi-temporal remote sensing data to manage the mangrove for coastal environmental protection. The International Archives of the Photogrammetry, Remote Sensing and Spatial Information Sciences, 37(B8): 709-712

Hong, P. N. 2004 Effects of mangrove restoration and conservation on the biodiversity and environment in Can Gio District. In: Vannucci, M. (ed.). Mangrove Management and Conservation: Present and Future, United Nations Uni. Press, pp. 324

Nguyen, V. L. 2011 Final report of mangrove forest structure and coverage change analysis using remote sensing and geographical information system technology a case study of Can Gio mangrove biosphere reserve, Ho Chi Minh City, Vietnam. Available online at https://www.rufford.org/files/48.12.09\%20Detailed\%20 Final\%20Report.pdf

van Loon, A. F., R. Dijksma and M. E. F. van Mensvoort 2007 Hydrological classification in mangrove areas: A case study in Can Gio, Vietnam. Aquatic Botany, 87: 80-82

Tuan, L. D., T. T. Oanh, C. V. Thanh and D. N. Qui 2002 Can Gio mangrove Biosphere Reserve. Agricultural Publishing House, Ho Chi Minh City, Vietnam

UNESCO/MAB Project 2000 Valuation of the mangrove ecosystem in Can Gio Biosphere Reserve, Vietnam. The Vietnam MAB National Committee. Available online at http://cmsdata. iucn.org/downloads/04_can_gio_mangrove_valuation.pdf 